\title{
A VALORAÇÃO COMO PROVA DOS ATOS PRATICADOS NO INQUÉRITO POLICIAL À LUZ DA LEI 13.964/191
}

\section{THE VALUTION OF INVESTIGATIVE FINDINGS AS PROOF UNDER RULE}

\subsection{4/19}

Vanessa Morais Kiss

Bacharel em Direito pela Universidade de São Paulo. Especialista em Direito Penal em Criminologia pelo Instituto de Criminologia e Política Criminal. Mestranda em Direito Processual Penal pela Pontifícia Universidade Católica de São Paulo. Defensora Pública do Estado de São Paulo. São Paulo, São Paulo, Brasil. E-mail: vanessamkiss@ gmail.com

RESUMO: O presente trabalho propõe-se a examinar a repercussão dos elementos informativos obtidos em fases anteriores sobre a formação do convencimento judicial na esfera penal, bem como os reflexos das modificações introduzidas pela Lei ${ }^{\circ}$ 13.964/19 neste particular, notadamente no que trata da criação da figura do juiz das garantias e da eliminação das peças do inquérito policial dos autos que serão remetidos ao juiz de instrução e julgamento.

PALAVRAS-CHAVE: Inquérito policial. Elementos informativos. Valoração. Prova. Juiz das garantias

\begin{abstract}
This paper aims to examine how investigative findings obtained in the early stages of criminal prosecution resonates on the final ruling, as well as the repercutions of the modifications introduced by "Lei $\mathrm{n}^{\circ} 13.964 / 19$ " in this matter, particularly in what concerns the creation of the "judge of guarantees" and the exclusion of preliminary pieces of evidence from the records that will be subjected to analysis by the judge of the case.
\end{abstract}

\footnotetext{
${ }^{1}$ Artigo recebido em 05/06/2020 e aprovado em 04/02/2021.
} 
KEYWORDS: Police investigation. Preliminary findings. Valutation. Proof. Judge of guarantees.

\begin{abstract}
"Na jurisdição, o fim não justifica os meios, dado que os meios, ou seja, as regras e as formas, são as garantias de verdade e de liberdade e, como tais têm valor para os momentos difíceis, assim como para os momentos fáceis."
\end{abstract}

Luigi Ferrajoli (Direito e razão, p. 667)

\title{
1. Introdução
}

A Lei ${ }^{\circ}$ 13.964/19, sancionada em 24 de dezembro de 2019, que ficou conhecida como "Pacote Anticrime", modificou o Código de Processo Penal para, entre diversas outras alterações, nele inserir art. $3^{\circ}$-C, cujo terceiro parágrafo passou a determinar: "Os autos que compõem as matérias de competência do juiz das garantias ficarão acautelados na secretaria desse juízo, à disposição do Ministério Público e da defesa, e não serão apensados aos autos do processo enviados ao juiz da instrução e julgamento, ressalvados os documentos relativos às provas irrepetíveis, medidas de obtenção de provas ou de antecipação de provas, que deverão ser remetidos para apensamento em apartado".

Tal dispositivo remete ao art. $3^{\circ}-\mathrm{B}$ do Código, também introduzido pela reforma legislativa, que trata das atribuições da figura, inédita em nosso sistema, do juiz de garantias, as quais compreendem o "controle da legalidade da investigação criminal" e a "salvaguarda dos direitos individuais cuja franquia tenha sido reservada à autorização prévia do Poder Judiciário".

Surge, então, a questão de como se compatibilizar esta nova sistemática com o conteúdo do art. 12 do Código de Processo Penal, mantido incólume pela nova lei, e que, por sua vez, dita: “O inquérito policial acompanhará a denúncia ou queixa, sempre que servir de base a uma ou outra".

É que, ao tratar da exclusão física do inquérito dos autos principais, o art. $3^{\circ}-\mathrm{C}$, em seu $\S 3^{\circ}$, já ressalva os documentos relativos às provas irrepetíveis, medidas de obtenção de provas ou de antecipação de provas, que deverão ser remetidos para apensamento em apartado. 
Resta estão, compreender se e em que medida subsiste a relevância do art. 12, ou, ainda, se houve, eventualmente, sua revogação tácita pelo já referido art. $3^{\circ}$-C , parágrafo $3^{\circ}$, todos do Código de Processo Penal vigente.

A investigação e elucidação desta aparente antinomia representa o primeiro objetivo do presente trabalho. Adicionalmente, buscar-se-á desvendar e compreender os novos delineamentos assumidos pelo antigo problema que dá nome a este artigo - a valoração probatória dos atos do inquérito policial - no novo contexto normativo que se apresenta, buscando-se contribuir para a construção um modelo interpretativo que seja apto a articular todas essas questões.

Para isso, no entanto, é necessário dar alguns passos atrás e examinar, ainda que brevemente, o problema que subjaz toda a discussão acerca do valor probatório dos atos da investigação - a saber, o papel atribuído à busca da verdade nos discursos que permeiam o processo penal e os usos que lhe têm sido dados nesse contexto.

\section{2. $O$ inquérito policial e a busca da verdade. A controversa redação do artigo 155 do Código de Processo Penal.}

A relação que aqui se vislumbra surge precisamente do texto vigente do artigo 155 do Código de Processo Penal, este totalmente mantido pela última reforma, e que versa: "O juiz formará sua convicção pela livre apreciação da prova produzida em contraditório judicial, não podendo fundamentar sua decisão exclusivamente nos elementos informativos colhidos na investigação, ressalvadas as provas cautelares, não repetíveis e antecipadas”.

Em breve retrospecto, a reforma processual promovida pela Lei ${ }^{\circ}$ 11.690/08 produziu uma pontual mas significativa alteração na redação no dispositivo que tratava da formação da convicção judicial. No modelo precedente, o artigo 157 versava que: “O juiz formará sua convicção pela livre apreciação da prova”, o que, em tese, permitia que a autoridade judicial fundamentasse sua convicção apenas com esteio no produto da investigação preliminar.

Ocorre que, neste ponto, a alteração legislativa que deu nova redação ao artigo 155 deixou de refletir o entendimento que já era dominante na doutrina e na jurisprudência, e de assentar claramente que ao juiz seria vedado basear-se em provas colhidas em sede 
inquisitorial. Ao invés disso, limitou-se a estabelecer que o julgador não pode "fundamentar sua decisão exclusivamente nos elementos informativos colhidos na investigação ressalvadas as provas cautelares, não repetíveis e antecipadas”.

Nota-se que, que o advérbio exclusivamente, inexistente no projeto apresentado pela comissão presidida por Ada Pelegrini Grinover (Projeto de Lei $\mathrm{n}^{\circ}$ 4.205/01), foi objeto de intenso debate durante a tramitação legislativa da reforma de 2008. Com efeito, o texto chegou a receber emenda no Senado voltada a retirar o termo da redação, o que implicaria que as informações colhidas na investigação não poderiam ser levadas em consideração pelo juiz sentenciante a qualquer título (salvo na hipótese de produção antecipada de provas); tal alteração, contudo, não prevaleceu na Câmara dos Deputados.

Assim, ao introduzir no texto o advérbio exclusivamente, o legislador autorizou, $a$ contrario sensu, a interpretação de que é possível utilizar elementos da investigação preliminar para fundamentar a sentença, desde que não isolados. Tal redação é alvo de intensa crítica doutrinária, segundo a qual o termo "exclusivamente" acaba por subverter a leitura adequada do dispositivo à luz do princípio acusatório - ou seja, de que os elementos da fase preliminar, em regra, servem apenas à formação da opinio delicti, com a consequente denúncia ou arquivamento, ao passo que o convencimento judicial deve imbuir-se apenas das informações carreadas pelas partes em juízo e sob o crivo do contraditório, observadas todas as garantias individuais implicadas.

Nesse sentido é a posição de Aury Lopes Jr. e Ricardo Jacobsen Gloeckner acerca da redação dada ao artigo 155: "Ora, isso é simbólico e fadado ao fracasso, pois não evita a contaminação consciente ou inconsciente do julgador. Os elementos do inquérito continuam dentro do processo e a vedação apenas fará com que os juízes lancem mão de um exercício de retórica para condenar com base no inquérito, sem dizê-lo de forma clara"2.

Desse modo, ao abrir ampla margem para o acesso e a utilização dos elementos investigativos pelo juiz sentenciante, o art. 155 trouxe para o terreno do inquérito policial o problema da busca de uma verdade, seja ela designada como real, formal ou processual, no bojo da persecução penal.

\footnotetext{
${ }^{2}$ GLOECKNER, Ricardo Jacobsen; LOPES JR. Aury. Investigação preliminar no processo penal, $6^{a}$ ed. São Paulo: Saraiva, 2014, p. 332.
} 
Revista Eletrônica de Direito Processual - REDP.

Rio de Janeiro. Ano 15. Volume 22. Número 2. Maio a Agosto de 2021

Periódico Quadrimestral da Pós-Graduação Stricto Sensu em Direito Processual da UERJ

Patrono: José Carlos Barbosa Moreira (in mem.). ISSN 1982-7636. pp. 714-735

www.redp.uerj.br

Ada Pelegrini Grinover ${ }^{3}$ rechaça a ideia de uma dualidade entre as noções de "verdade real" e "verdade formal", que considera um falso problema, bem como a associação da primeira ao processo penal e da segunda ao processo civil. Defende a autora que, em ambos os casos, ao juiz compete somente a busca de uma verdade processual, compreendida como "o estágio mais próximo possível da certeza". E, para mais se aproximar deste objetivo e, em última análise, do ideal de pacificação com justiça, seria necessário dotar a atividade judicial, também no âmbito penal, de iniciativa instrutória.

E, no que diz respeito ao alcance dos de tais poderes instrutórios - e sua não extensão à fase de investigação prévia - esclarece a doutrinadora ${ }^{4}$ :

\begin{abstract}
"Não se confunda o que se disse quanto aos poderes do juiz no processo e à sua iniciativa probatória com a atribuição de poderes para buscar elementos probatórios durante a fase da investigação prévia. Esta não pode ser confiada ao juiz, sob pena de se retornar ao juiz-inquisidor do modelo antigo. Durante a investigação, o juiz do processo acusatório tem apenas a função de determinar providências cautelares. Por isso, é oportuno que o juiz da investigação prévia (a cargo do Ministério Público e/ou da polícia judiciária) seja diverso do juiz do processo. É neste, e somente neste, que deve ser estimulada a iniciativa oficial."
\end{abstract}

Em semelhante sentido, Eugenio Pacelli ${ }^{5}$, sem ignorar que a verdade histórica se situa além do alcance do processo penal, argumenta que este tem como uma de suas funções essenciais o compromisso com a verdade material, concebida como uma espécie de verdade a ser construída segundo as regras do devido processo e com respeito às garantias individuais. Segundo sua compreensão, "toda interpretação do sistema processual penal deverá levar em conta a necessidade de esclarecimento da verdade como um vetor estratégico, e que se põe no mesmo plano de validade da potencialização dos direitos e garantias individuais"

De acordo com Luigi Ferrajoli ${ }^{7}$, a verdade formal, ou processual, em contraste com a verdade substancial, é uma verdade mais controlada quanto ao método de aquisição (pois

\footnotetext{
${ }^{3}$ GRINOVER, Ada Pellegrini. Verdade real e verdade formal? Um falso problema. In: PEREIRA, Flávio Cardoso. Verdade e prova no processo penal: Estudos em homenagem ao professor Michele Taruffo, $1^{\mathrm{a}}$ ed. Brasília: Gazeta Jurídica, 2016, p. 9.

${ }^{4}$ Ibidem, p. 8.

${ }^{5}$ PACELLI, Eugênio. Verdade judicial e sistema de prova no processo penal brasileiro. In: PEREIRA, Flávio Cardoso. Verdade e prova no processo penal: Estudos em homenagem ao professor Michele Taruffo, $1^{\mathrm{a}}$ ed. Brasília: Gazeta Jurídica, 2016, p. 92-93.

${ }^{6}$ Ibidem, p. 100.

${ }^{7}$ FERRAJOLI, Luigi. Direito e razão: teoria do garantismo penal. $3^{\mathrm{a}}$ ed. São Paulo: Ed. Revista dos Tribunais, 2002 , p. 38.
} 
condicionada pelo respeito aos procedimentos e às garantias individuais), porém mais limitada quando ao conteúdo, sendo sempre uma verdade meramente provável e opinativa. Trata-se de uma opção epistemológica do sistema jurídico voltado à proteção da liberdade dos cidadãos contra arbitrariedades. $\mathrm{O}$ valor do formalismo está em presidir normativamente a indagação judicial, protegendo a liberdade dos indivíduos contra a introdução de verdades substancialmente arbitrárias ou incontroláveis.

Na leitura de GLOECKNER e LOPES JR. ${ }^{8}$, seria equivocado atribuir uma presunção de veracidade aos atos de investigação, e assim porque o fundamento do art. 12 do Código de Processo Penal, ao estabelecer que o inquérito policial acompanhará a denúncia ou queixa quando lhes servir de base, não é atribuir valor probatório aos atos deste procedimento, que tem caráter instrumental e sumário, mas somente possibilitar o juízo de pré-admissibilidade da acusação. Ademais, fosse esta sua intenção, poderia o legislador de 1941, de maneira expressa, atribuir tal valor probatório aos atos do inquérito. ${ }^{9}$

Observam os autores que, com a redação dada ao art. 155 do CPP após a reforma de 2008, vedou-se, por um lado, a fundamentação do convencimento judicial exclusivamente com base nos elementos informativos provenientes da investigação; porém, com o emprego do termo "exclusivamente", abriu-se ampla margem para o uso de tais elementos, desde que cotejados com outros da instrução criminal, sendo estes frequentemente utilizados para simples chancela dos atos da investigação. Destaca, ainda, que a procura de uma verdade inalcançável e a invocação de um alegado interesse público tem sido historicamente empregadas para justificar inúmeras violências ao cidadão ${ }^{10}$. No processo penal só é possível falar-se em uma verdade formal ou processual, passível apenas de ser produzida com atenta observância aos controles legais ${ }^{11}$. Esta verdade processual, de caráter aproximativo e contingente, não confunde com uma verdade real, esta impossível de ser obtida, pois o real só existe no presente, enquanto os fatos passados habitam o campo da memória e do imaginário $^{12}$.

8 GLOECKNER, Ricardo Jacobsen; LOPES JR. Aury. Investigação preliminar no processo penal, $6^{a}$ ed. São Paulo: Saraiva, 2014, p. 300.

${ }^{9}$ Ibidem, p. 301.

${ }^{10}$ Ibidem, p. 303.

${ }^{11}$ Ibidem, p. 304.

${ }^{12}$ Ibidem, p. 305-306. 
Trata-se de entendimento compartilhado por Salah H. Khaled Jr. ${ }^{13}$, para quem a perseguição obstinada da verdade representa um dos traços distintivos fundamentais entre uma epistemologia inquisitória e persecutória, orientada para a obtenção da condenação em detrimento dos interesses do acusado, e uma epistemologia acusatória e democrática, pautada pelas exigências de contenção do poder punitivo. $\mathrm{O}$ processo penal acusatório de inspiração constitucional, portanto, não se compatibiliza com a figura do juiz que, como se pilotasse o laboratório da história, assume o protagonismo probatório e parte obstinadamente em busca da verdade.

Em que pese a força das vozes que enxergam com desconfiança o modelo processual penal que se pretende o caminho para a verdade e não mede esforços para alcançá-la, não há como ignorar a tenacidade deste ideal na cultura judicial e sua materialização nas decisões ela que tem produzido. Mais ainda, a compreensão da questão em sua complexidade passa pelo reconhecimento de que o convencimento quanto à formatação de uma tal verdade extrapola a relação processual e está inevitavelmente amarrada à investigação que precede sua formação. Não obstante, as alterações introduzidas pela Lei $n^{\circ}$ 13.964/19 lançam novas luzes sobre a questão da relação entre o inquérito policial e a formação do convencimento do juiz sentenciante no âmbito penal.

\section{Os meios de prova típicos e os sucedâneos de prova no processo penal}

Em seu trabalho Tipicidade e sucedâneos de prova, Antonio Scarance Fernandes, remetendo-se à lição Antonio Laronga, parte da distinção entre a noção de prova típica aquela que é prevista e regida por procedimento próprio - e prova atípica - a que, sendo ou não expressamente prevista na legislação, não é dotada de rito próprio para sua produção ${ }^{14}$. Assim, para a doutrina que adota tal distinção, são considerados atípicos tanto os meios de

\footnotetext{
${ }^{13}$ KHALED JR, Salah H. O caráter alucinatório da evidência e o sentido da atividade probatória: rompendo com a herança inquisitória e a filosofia da consciência. In: PEREIRA, Flávio Cardoso. Verdade e prova no processo penal: Estudos em homenagem ao professor Michele Taruffo, $1^{\mathrm{a}}$ ed. Brasília: Gazeta Jurídica, 2016, p. 295-296.

${ }^{14}$ FERNANDES, Antonio Scarance. Tipicidade e sucedâneos de prova. In: ALMEIDA, José Raul Gavião; FERNANDES, Antonio Scarance; MORAES, Mauricio Zanoide de (coord.). Provas no processo penal: estudo comparado. São Paulo: Saraiva, 2011, p. 15.
} 
Revista Eletrônica de Direito Processual - REDP.

Rio de Janeiro. Ano 15. Volume 22. Número 2. Maio a Agosto de 2021

Periódico Quadrimestral da Pós-Graduação Stricto Sensu em Direito Processual da UERJ

Patrono: José Carlos Barbosa Moreira (in mem.). ISSN 1982-7636. pp. 714-735

www.redp.uerj.br

prova não previstos pelo legislador como aqueles que, embora nominados, não contam com procedimento probatório específico ${ }^{15}$.

Nesses termos, seriam provas típicas aquelas efetivadas segundo procedimentos descritos nos ordenamentos processuais penais, tal como usualmente se dá com os meios de prova testemunhal, pericial, documental, e com o reconhecimento de pessoas e coisas ${ }^{16}$. Por outro lado, exemplos de meios de prova atípicos, em alguns sistemas, seriam a acareação, a reconstrução e a reconstituição do crime - tudo a depender da disciplina delineada por cada modelo.

No Brasil, adota-se o paradigma da não taxatividade dos meios de prova, sendo possível a produção de provas não previstas na legislação ${ }^{17}$. Entretanto, conforme destaca Fernandes ${ }^{18}$, "a admissibilidade de uma prova atípica deve estar sujeita a critérios mais rígidos e ser marcada pela excepcionalidade, e, por isso, deve obedecer a parâmetros de validade mais exigentes do que os das provas tipificadas" - sem prejuízo, a toda evidência, dos parâmetros que balizam a produção de qualquer espécie de prova, notadamente a vedação às provas obtidas por meios ilícitos e com desrespeito às garantias e liberdades fundamentais. Contudo, uma vez que os meios atípicos não contam com regramento procedimental próprio, e tampouco há previsão de um rito genérico que a eles possa ser aplicado, sua materialização passa, com frequência, pelo recurso analógico de outros procedimentos já formatados pelo legislador ${ }^{19}$.

A noção de sucedâneo de prova, por sua vez, refere-se aos casos em que, diante da insuficiência dos elementos de informação obtidos a partir dos meios de prova regulados pelo legislador, utilizam-se conhecimento diversamente obtidos na formação do convencimento judicial ${ }^{20}$. Assim, partindo-se de uma compreensão restritiva de prova como

\footnotetext{
15 BADARÓ, Gustavo Henrique Righi Ivahy; GOMES FILHO, Antonio Magalhães. Prova e sucedâneos de prova no processo penal brasileiro. Revista Brasileira de Ciências Criminais, n. 65, mar-abr/2007, p. 175-176. ${ }^{16}$ Não obstante a menção no artigo 239 do Código de Processo Penal, o indício não constitui meio de prova autônomo, e sim um fato demonstrado a partir do qual o juiz deduz a existência de outro fato (Ibidem, p. 197). ${ }^{17}$ Ibidem, p. 180-181.

${ }^{18}$ FERNANDES, Antonio Scarance. Tipicidade e sucedâneos de prova. In: ALMEIDA, José Raul Gavião; FERNANDES, Antonio Scarance; MORAES, Mauricio Zanoide de (coord.). Provas no processo penal: estudo comparado. São Paulo: Saraiva, 2011, p. 28.

${ }^{19}$ Ibidem, p. 30-31.

${ }^{20}$ BADARÓ, Gustavo Henrique Righi Ivahy; GOMES FILHO, Antonio Magalhães. Prova e sucedâneos de prova no processo penal brasileiro. Revista Brasileira de Ciências Criminais, n. 65, mar-abr/2007, p. 175.
} 
Revista Eletrônica de Direito Processual - REDP.

Rio de Janeiro. Ano 15. Volume 22. Número 2. Maio a Agosto de 2021

Periódico Quadrimestral da Pós-Graduação Stricto Sensu em Direito Processual da UERJ

Patrono: José Carlos Barbosa Moreira (in mem.). ISSN 1982-7636. pp. 714-735

www.redp.uerj.br

sendo aquilo que é produzido durante instrução desenvolvida sob o contraditório processual, seriam considerados sucedâneos os elementos colhidos em fases anteriores ${ }^{21}$.

Quanto ao fenômeno dos sucedâneos probatórios, Fernandes ${ }^{22}$ afirma tratar-se um vício processual que "consiste no uso, como prova, daquilo que não é verdadeira prova, normalmente em decorrência de dois fatos: o uso na audiência de julgamento, como elementos probatórios de elementos colhidos nas fases anteriores, e a substituição de um meio de prova por outro". Ao presente trabalho, interessa, particularmente, a primeira hipótese.

O estudo comparativo da matéria revelou que diversos ordenamentos processuais penais (Argentina, Costa Rica, Chile, Colômbia e Portugal) contêm vedação expressa ao emprego de elementos convicção das fases preliminares para fins de julgamento. Todavia, todos eles contemplam exceções que relativizam e proibição e, em alguma medida, possibilitam a incorporação de tais elementos à instrução, tal como ocorre nos casos de produção antecipada de provas, em situações de urgência, ante o perigo de perecimento da fonte ${ }^{23}$.

No que diz com a sistemática processual penal brasileira, não existia, até a reforma de 2008, proibição expressa do uso dos elementos de convicção colhidos na investigação para a fundamentação do convencimento judicial. Esta vedação, há muito defendida por significativa parcela da doutrina ${ }^{24}$, foi introduzida pela nova redação dada ao artigo 155 do Código de Processo Penal, que, contudo, ao ressalvar sua própria razão de ser com a inclusão do advérbio "exclusivamente", perpetuou a incerteza sobre a questão. Sobre a controvérsia, sustentou ${ }^{25}$ :

\footnotetext{
“(...) a melhor interpretação é a que vê, na reforma, profunda alteração no esquema anterior, pois somente ela se afina com os postulados do contraditório e da ampla defesa e alinha o país aos que, como visto, proíbem a utilização no julgamento de elementos anteriormente obtidos, não os admitindo como sucedâneos de prova.
}

\footnotetext{
${ }^{21}$ FERNANDES, Antonio Scarance. Tipicidade e sucedâneos de prova. In: ALMEIDA, José Raul Gavião; FERNANDES, Antonio Scarance; MORAES, Mauricio Zanoide de (coord.). Provas no processo penal: estudo comparado. São Paulo: Saraiva, 2011, p. 14.

22 Ibidem, p. 30.

${ }^{23}$ Ibidem, p. 30-31.

${ }^{24}$ MARQUES, José Frederico. Tratado de direito processual penal, v.1. São Paulo: Saraiva, 1980, p. 194.

${ }^{25}$ FERNANDES, Antonio Scarance. Tipicidade e sucedâneos de prova. In: ALMEIDA, José Raul Gavião; FERNANDES, Antonio Scarance; MORAES, Mauricio Zanoide de (coord.). Provas no processo penal: estudo comparado. São Paulo: Saraiva, 2011, p. 35.
} 
Revista Eletrônica de Direito Processual - REDP.

Rio de Janeiro. Ano 15. Volume 22. Número 2. Maio a Agosto de 2021

Periódico Quadrimestral da Pós-Graduação Stricto Sensu em Direito Processual da UERJ

Patrono: José Carlos Barbosa Moreira (in mem.). ISSN 1982-7636. pp. 714-735

www.redp.uerj.br

Assim, não pode o juiz, independentemente do que conste na lei, considerar como prova aquilo que não foi colhido mediante contraditório judicial. No caso, aliás, é o que estipula o caput do art. 155. O uso do vocábulo 'exclusivamente' para afirmar que essa regra não é absoluta significa que há possibilidade excepcional de ser considerado como prova elemento obtido durante a investigação. O próprio artigo indica quando isso será admissível: prova antecipada, prova irrepetível, prova cautelar.”

Badaró e Gomes Filho ${ }^{26}$ observam que, no Brasil, a participação das partes na etapa investigativa está contemplada, no caso no Ministério Público, no artigo 129, VII da Constituição Federal, que trata do controle externo da atividade policial e, no caso da defesa, no artigo $7^{\circ}$, XIV da Lei $n^{\circ} 8.906 / 94$ (Estatuto da OAB) ${ }^{27}$; contudo, na prática, as diligências preliminares tendem a se desenvolver de forma alheia a estes atores. Desse modo, os elementos da fase prévia não equivalem às provas na acepção própria do termo, pois destinam-se a subsidiar a opinião do órgão acusador e o entendimento do julgador acerca da admissão da acusação, bem como sobre eventuais providências cautelares ${ }^{28}$.

Daí falar a exposição de motivos do Código de Processo penal em instrução provisória para designar aquela que serve à formação do juízo provisório de admissibilidade da acusação, em contraste com a instrução definitiva ou propriamente dita, voltada ao juízo definitivo sobre seu conteúdo ${ }^{29}$.

Contudo, como não havia, até a Lei no 13.964/19 qualquer regra prevendo a exclusão física das diligências preliminares dos autos principais, é certo que tais elementos de convicção acabavam por ter inevitável influência na persuasão do juiz sentenciante. No

\footnotetext{
${ }^{26}$ BADARÓ, Gustavo Henrique Righi Ivahy; GOMES FILHO, Antonio Magalhães. Prova e sucedâneos de prova no processo penal brasileiro. Revista Brasileira de Ciências Criminais, n. 65, mar-abr/2007, p. 193.

${ }^{27} \mathrm{E}$, mais recentemente, também no Provimento CFOAB n ${ }^{\circ} 188 / 2018$, que versa sobre a chamada investigação defensiva, também tratada no PLS no 156/2009 em trâmite.

${ }^{28}$ Nesse sentido: "De qualquer modo, não há dúvida que a finalidade última da investigação formal chamada inquérito policial é ministrar elementos para que o titular da ação penal possa acusar o autor do crime e/ou da contravenção. (...) Cumpre, no entanto, acentuar que o inquérito policial pode servir de base também para absolver, para a decretação de medidas cautelares, pessoais ou patrimoniais, para a declaração da extinção da punibilidade etc." (TOVO, Paulo Cláudio. Democratização do Inquérito Policial. In: TOVO, Paulo Cláudio (coord.). Estudos de Direito Penal, v. 2. Porto Alegre: Livraria do Advogado, 1999, p. 200-201). E ainda: "Como regra geral, pode-se afirmar que o valor dos elementos coligidos no curso do inquérito policial somente servem para fundamentar medidas de natureza endoprocedimental (cautelares etc.) e, no momento da admissão da acusação, para justificar o processo ou o não processo (arquivamento)." (GLOECKNER, Ricardo Jacobsen; LOPES JR. Aury. Investigação preliminar no processo penal, $6^{a}$ ed. São Paulo: Saraiva, 2014, p. 322)

${ }^{29}$ TOVO, Paulo Cláudio. Democratização do Inquérito Policial. In: TOVO, Paulo Cláudio (coord.). Estudos de Direito Penal, v. 2. Porto Alegre: Livraria do Advogado, 1999, p. 200.
} 
Revista Eletrônica de Direito Processual - REDP.

Rio de Janeiro. Ano 15. Volume 22. Número 2. Maio a Agosto de 2021

Periódico Quadrimestral da Pós-Graduação Stricto Sensu em Direito Processual da UERJ

Patrono: José Carlos Barbosa Moreira (in mem.). ISSN 1982-7636. pp. 714-735

www.redp.uerj.br

entanto, as modificações introduzidas pela referida lei e, particularmente, a redação dada ao artigo $3^{\circ}$-C, parágrafo $3^{\circ}$ do Código de Processo Penal, conferem novos contornos a questão, que serão objeto do capítulo seguinte.

\section{A valoração probatória dos elementos informativos e a questão da exclusão física do inquérito à luz da Lei no $13.964 / 19$}

\subsection{O experimento de Schünemann}

Bernd Schünemann ${ }^{30}$ descreve interessante experimento em que 58 juízes e promotores alemães foram chamados a atuar na apreciação de um processo criminal simulado, cujo material foi extraído de um caso real em que o réu fora acusado do crime de libertação de preso, tomando-se como variáveis: i) a existência ou inexistência de conhecimento prévio dos autos de investigação preliminar; ii) a possibilidade ou não de o julgador inquirir as testemunhas em audiência de instrução.

O resultado revelou que todos os juízes que tiveram acesso aos autos de investigação acabaram condenando o acusado, enquanto, dentre aqueles que não tinham esse conhecimento prévio, a maior parte decidiu pela absolvição. O teste demonstrou também a presença do efeito inércia (perseverança do julgamento) no momento da decisão, na medida em que os participantes que conheciam o teor da investigação se recordaram com menor clareza das respostas apresentadas pelas testemunhas em audiência ${ }^{31}$ :

"O efeito inércia fez-se aqui presente no sentido de que os juízes dotados de conhecimento dos autos não apreenderam e não armazenaram corretamente o conteúdo defensivo presente na audiência de instrução e julgamento, porque eles só apreendiam e armazenavam as informações incriminadoras, que já lhes eram conhecidas ('redundantes') em razão da leitura prévia dos autos."

\footnotetext{
${ }^{30}$ SCHÜNEMANN, Bernd. O juiz como um terceiro manipulado no processo penal? Uma confraternização empírica dos efeitos perseverança e aliança. In: GRECO, Luís (coord.). Estudos de direito penal, direito processual penal e filosofia do direito. São Paulo: Marcial Pons, 2013, p. 209-210.

${ }^{31}$ Ibidem, p. 211-212.
} 
Ao debruçar-se sobre a experiência em questão, Pacelli ${ }^{32}$ afirma que suas conclusões confirmam uma antiga hipótese formulada por Schünemann acerca dos pré-julgamentos judiciais no processo penal alemão, que se manifestam por meio de quatro efeitos visíveis: o da perserverança (tendência dos juízes a confirmar a impressão obtida no ato de recebimento da denúncia); o da redundância (preferência por aquilo que soa como repetição do material previamente apreendido); o da atenção (menor atenção em relação às informações contrárias às impressões iniciais, sobretudo quando não há possibilidade de inquirição das testemunhas pelo juiz); e o efeito aliança (tendência do magistrado aceitar a credibilidade do membro do Ministério Público e, assim, limitar-se a ratificar a acusação).

Ainda segundo Pacelli (2016, p. 94), por consequência destes efeitos, notadamente os da perseverança e da redundância, a vinculação do órgão julgador a uma decisão prévia que ele tenha tomado no processo "parece tornar absolutamente irrelevante o contraditório, diante da dissociação cognitiva que manteria o juiz a partir de sua impressão inicial, tendendo a não estar atento às informações (provas e argumentações) em sentido contrário".

Em semelhante sentido, interpretando os resultados obtidos, Schünemann anota que, as tendências observadas, e confirmadas em sua própria experiência como advogado, fazem com que "o princípio in dubio pro reo seja na audiência posto faticamente de ponta-cabeça, porque o advogado se vê incumbido de provar a incorreção da denúncia, caso ele realmente queira conseguir uma absolvição". Daí que, segundo conclui, o melhor resultado em termos de processamento de informações seria obtido por um juiz sem conhecimento prévio do teor da investigação preliminar, mas dotado de direitos próprios de inquirição ${ }^{33}$.

\subsection{O valor dos elementos repetíveis e não-repetíveis obtidos no inquérito}

Como já se afirmou, os atos praticados no inquérito policial possuem função eminentemente endoprocedimental, com eficácia probatória limitada à fase investigativa, destinando-se a justificar as decisões interlocutórias proferidas em seu curso e fundamentar

\footnotetext{
${ }^{32}$ PACELLI, Eugênio. Verdade judicial e sistema de prova no processo penal brasileiro. In: PEREIRA, Flávio Cardoso. Verdade e prova no processo penal: Estudos em homenagem ao professor Michele Taruffo, $1^{\mathrm{a}}$ ed. Brasília: Gazeta Jurídica, 2016, p. 90.

${ }^{33}$ SCHÜNEMANN, Bernd. O juiz como um terceiro manipulado no processo penal? Uma confraternização empírica dos efeitos perseverança e aliança. In: GRECO, Luís (coord.). Estudos de direito penal, direito processual penal e filosofia do direito. São Paulo: Marcial Pons, 2013, p. 216-217.
} 
a probabilidade do fumus comissi delicti necessário à instauração do processo ${ }^{34}$. No entanto, além de servirem à fundamentação de medidas internas aptas a restringir a liberdade pessoal e a disponibilidade de bens, não se pode ignorar que, em certos casos, aos atos do inquérito é atribuída uma transcendência valorativa incompatível com sua natureza preponderantemente informativa ${ }^{35}$.

É que os atos praticados nesta fase, enquanto atos de investigação, como regra, são praticados perante em um contexto inquisitivo caracterizado pelo sigilo, pela forma escrita e pela restrição ao contraditório ${ }^{36}$, sem a participação do órgão jurisdicional, não se prestado a gerar elementos de convicção valoráveis para justificar uma condenação.

Isso posto, Tovo $^{37}$ propõe a classificação dos elementos obtidos no inquérito policial em renováveis ou repetíveis; não-renováveis ou não-repetíveis; e provas prontas. Segundo o autor, as provas renováveis oriundas da fase inquisitorial teriam valor meramente informativo, não podendo, sob pena de violação ao contraditório e à ampla defesa, servir de base ou sequer apoiar subsidiariamente a condenação. Contudo, não há óbice para que subsidiem a absolvição. Já quantos às provas não-repetíveis, para que sejam utilizadas na instrução, exige-se que sejam colhidas na presença fiscalizante da defesa técnica. Enfim, designa como provas prontas as que estão acabadas antes da deflagração da persecução penal e, por esse motivo, não seria exigível a observância do contraditório e da ampla defesa no momento de sua formação.

Nesses termos, para que possam ser valoradas na sentença, as provas repetíveis, tal como a testemunhal, devem ser renovadas na fase processual, perante a autoridade judicial e na presença das partes, com atenção às formalidades legais. Não satisfazem a exigência de repetição a mera leitura, pelo juiz ou pelas partes, do testemunho anteriormente prestado, e tampouco a simples ratificação do depoimento prévio, devendo ser observadas as exigências da oralidade e da imediação processo. ${ }^{38}$

\footnotetext{
${ }^{34}$ GLOECKNER, Ricardo Jacobsen; LOPES JR. Aury. Investigação preliminar no processo penal, $6^{\mathbf{a}}$ ed. São Paulo: Saraiva, 2014, p. 326.

${ }^{35}$ Ibidem, p. 322.

${ }^{36}$ TOURINHO FILHO. Fernando da Costa. Processo Penal, v. 1. São Paulo: Saraiva, 1999, p.13.

${ }^{37}$ TOVO, Paulo Cláudio. Democratização do Inquérito Policial. In: TOVO, Paulo Cláudio (coord.). Estudos de Direito Penal, v. 2. Porto Alegre: Livraria do Advogado, 1999, p. 201-202.

${ }^{38}$ GLOECKNER, Ricardo Jacobsen; LOPES JR. Aury. Investigação preliminar no processo penal, $6^{\mathrm{a}}$ ed. São Paulo: Saraiva, 2014, p. 323-325.
} 
Por outro lado, com relação às provas irrepetíveis ou perecíveis pelo decurso do tempo, como o exame de corpo de delito, é possível, excepcionalmente, a produção antecipada $^{39}$. Ainda assim, é preciso que sejam colhidas com certas cautelas, em atenção ao artigo $5^{\circ}$, LV da Constituição Federal, sendo mister oportunizar-se manifestação da defesa, seja para postular outras provas; requerer determinado tipo de análise ou de meios; ou formular quesitos aos peritos ${ }^{40}$.

Sobre a função do incidente de produção antecipada da prova, esclarecem Gloeckner e Lopes Jr. que se trata de "uma forma de jurisdicionalizar a atividade probatória no curso do inquérito, através da prática do ato ante uma autoridade jurisdicional e com plena

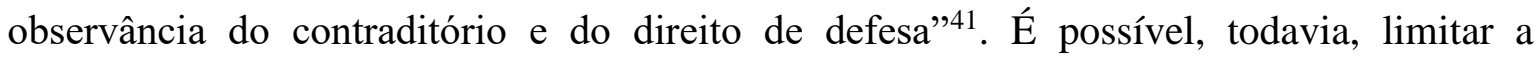
publicidade externa quando necessário evitar prejuízos para a investigação e a prematura estigmatização social do sujeito. Assim, a produção antecipada de provas permite que certo elemento informativo que deveria, em princípio, ser repetido na fase processual, seja produzido uma única vez, ainda na fase de investigação, com a observância das cautelas necessárias para que seja elevado ao patamar de prova, isso é, para que possa ser valorado na sentença.

Com o advento da Lei ${ }^{\circ} 11.689 / 08$, introduziu-se no Código de Processo Penal a figura da medida cautelar de produção antecipada de provas (artigo 156, I), que poderia, em tese, ser requerida pelas partes interessadas ou determinada de ofício pelo juiz ${ }^{42}$. No âmbito do processo civil, há muito já era adotado o instituto da justificação (artigos 846 a 851 do CPC/1973 e artigos 381 a 383 do CPC/2015). No entanto, até então, o diploma processual penal limitava-se a mencionar, em seu artigo 225 , a possibilidade de colheita antecipada da prova oral nos casos em que houvesse risco de perecimento.

Embora ausente previsão expressa nesse sentido, defende $\mathrm{Nucci}^{43}$ que, para que a prova antecipada possa ser valorada na sentença, é necessária a designação de audiência pelo

\footnotetext{
39 "O novel instituto pode ser promissor, desde que utilizado com cautela e prudência, sem a finalidade de antecipar, com frequência, a produção de provas durante a fase investigatória.” (NUCCI, Guilherme de Souza. Provas no processo penal, $4^{\mathrm{a}}$ ed. Rio de Janeiro: Forense, 2015, p. 42)

${ }^{40}$ Ibidem, p. 326.

${ }^{41}$ Ibidem, p. 328.

${ }^{42}$ A previsão da possibilidade de determinação de ofício é considerada inconstitucional por parte da doutrina. Cf. OLIVEIRA, Eugênio Pacelli de. Curso de processo penal, 10ª ed. Rio de Janeiro: Lumen Juris, 2008, p. 288.

${ }^{43}$ NUCCI, Guilherme de Souza. Provas no processo penal, $4^{\mathrm{a}}$ ed. Rio de Janeiro: Forense, 2015, p. 43.
} 
Revista Eletrônica de Direito Processual - REDP.

Rio de Janeiro. Ano 15. Volume 22. Número 2. Maio a Agosto de 2021

Periódico Quadrimestral da Pós-Graduação Stricto Sensu em Direito Processual da UERJ

Patrono: José Carlos Barbosa Moreira (in mem.). ISSN 1982-7636. pp. 714-735

www.redp.uerj.br

órgão julgador, com a presença das partes interessadas, dando-se efetividade ao mandamento constitucional do artigo $5^{\circ}, \mathrm{LV}$ da Constituição Federal. É imprescindível a intimação do indiciado, ou caso ainda não tenha havido indiciamento, de todos os suspeitos. Caso estes não tenham constituído advogado, atuará a Defensoria Pública ou, onde ela não estiver estruturada, será nomeado defensor dativo.

Ainda que reconheça sua utilidade prática, a doutrina ressalta o caráter extraordinário da providência, a ser admitida somente em casos extremos, em que restarem evidenciadas, de um lado, a relevância da prova em questão e, de outro, a inviabilidade de sua posterior repetição na fase processual ${ }^{44}$. Cuida-se de uma exceção, e sob tal ótica devem ser examinadas sua urgência e relevância, não se admitindo, sob qualquer pretexto, sua vulgarização com o mero intuito de facilitar a produção probatória ${ }^{45}$.

Em síntese, no que diz com a valoração probatória dos elementos do inquérito, e retomando a questão da busca da verdade no processo penal, é possível concluir que, conforme a lição de Gloeckner e Lopes Jr. ${ }^{46}$ :

“Claro está que só a prova judicial é válida, pois o que se pretende não é a verdade material - obtida a qualquer custo -, mas, sim, a formalmente válida, produzida no curso do processo penal. Ou há prova suficiente no processo para condenar, e o veredicto deve ser esse, ou permanece a dúvida, e a absolvição é o único caminho. Recordemos que a dúvida, a falta de acusação ou de provas ritualmente formadas impõem a prevalência da presunção de inocência e atribuição de falsidade formal ou processual às hipóteses acusatórias."

44 GLOECKNER, Ricardo Jacobsen; LOPES JR. Aury. Investigação preliminar no processo penal, $6^{\mathrm{a}}$ ed. São Paulo: Saraiva, 2014, p. 327.

${ }^{45}$ NUCCI, Guilherme de Souza. Provas no processo penal, $4^{\mathrm{a}}$ ed. Rio de Janeiro: Forense, 2015, p. 44-45. Nesse sentido, também merece referência a posição já advogada por BADARÓ e GOMES FILHO (op.cit., p. 194-195) anteriormente à Lei $n^{\circ} 11.689 / 08$, no tocante à prova pericial: "Nesse caso, é comum a realização de perícias, em especial do exame de corpo de delito, na fase policial, embora tal prova seja utilizada, posteriormente, pelo juiz para fim fundamentar o seu convencimento. Tal entendimento é correto somente nos casos em que a perícia tenha natureza cautelar, de produção antecipada de prova, não podendo ser realizada em momento posterior. Neste caso, na fase judicial, a perícia será submetida ao contraditório diferido. De outro lado, se não se estiver diante de uma perícia determinada cautelarmente, a prova técnica deverá ser realizada em juízo, com a possibilidade de contraditório prévio, especialmente pela faculdade das partes formularem quesitos, inclusive com a possibilidade de acompanhamento da própria realização dos exames pelos interessados. Se não há urgência na prova, não deve ser aceita a perícia produzida na fase de investigação, sem o prévio contraditório e sem mesmo a participação judicial. Em tal caso, a perícia deve ser realizada somente em juízo e não na fase de investigação preliminar."

${ }^{46}$ GLOECKNER, Ricardo Jacobsen; LOPES JR. Aury. Investigação preliminar no processo penal, $6^{\text {a }}$ ed. São Paulo: Saraiva, 2014, p. 329. 


\title{
4.3. A exclusão do inquérito policial e a redação dada ao artigo $3^{\circ}$-C, parágrafo $3^{\circ}$ do Código de Processo Penal
}

Em que pesem as considerações expostas acerca do caráter provisório dos elementos informativos colhidos na investigação, Badaró e Gomes Filho ${ }^{47}$ observavam, já em 2007, que, em virtude do disposto no artigo 12 do Código de Processo Penal ${ }^{48}$, a documentação de tais atos permanecia inclusa nos autos da ação penal após o recebimento da denúncia, repercutindo, ainda que não declaradamente, na formação do convencimento do juiz sentenciante.

Nesse caso, segundo os autores, não haveria, propriamente, ilicitude das provas indevidamente produzidas na fase pré-processual, e sim nulidade da sentença que nelas se fundamentasse, por desrespeito à garantia constitucional do contraditório ${ }^{49}$ :

\begin{abstract}
"A questão, contudo, se coloca sob o ponto de vista ou nulidade do ato final, no caso, a sentença. Se na sentença o juiz se utilizar, exclusivamente, de elementos de informação produzidos no inquérito policial, haverá um erro de julgamento. Em grau de recurso, o Tribunal poderá modificar tal decisão, absolvendo o acusado. Não há, portanto, uma ilicitude de tais provas e, muito menos, nulidade pelo fato destas terem permanecido nos autos. Todo o controle será feito pela motivação da sentença."
\end{abstract}

No mesmo sentido, Gloeckner e Lopes Jr. ${ }^{50}$ sustentavam que, embora o artigo 155 vede simbolicamente a valoração de elementos de informação da fase investigativa para fins de condenação, o fato de o inquérito acompanhar a acusação e passar a integrar os autos principais faz surgir grave risco de contaminação, consciente ou inconsciente, da percepção do julgador.

\footnotetext{
${ }^{47}$ BADARÓ, Gustavo Henrique Righi Ivahy; GOMES FILHO, Antonio Magalhães. Prova e sucedâneos de prova no processo penal brasileiro. Revista Brasileira de Ciências Criminais, n. 65, mar-abr/2007, p. 195.

48 "Artigo 12. O inquérito policial acompanhará a denúncia ou queixa, sempre que servir de base a uma ou outra."

${ }^{49}$ BADARÓ, Gustavo Henrique Righi Ivahy; GOMES FILHO, Antonio Magalhães. Prova e sucedâneos de prova no processo penal brasileiro. Revista Brasileira de Ciências Criminais, n. 65, mar-abr/2007, p. 199.

${ }^{50}$ GLOECKNER, Ricardo Jacobsen; LOPES JR. Aury. Investigação preliminar no processo penal, $6^{a}$ ed. São Paulo: Saraiva, 2014, p. 328.
} 
Revista Eletrônica de Direito Processual - REDP.

Rio de Janeiro. Ano 15. Volume 22. Número 2. Maio a Agosto de 2021

Periódico Quadrimestral da Pós-Graduação Stricto Sensu em Direito Processual da UERJ

Patrono: José Carlos Barbosa Moreira (in mem.). ISSN 1982-7636. pp. 714-735

www.redp.uerj.br

Ocorre que as recentes alterações promovidas na legislação penal e processual penal pela Lei $n^{\circ} 13.964 / 19$, popularmente conhecida como o "Pacote Anticrime", tornam necessária a releitura da questão sob nova perspectiva.

Inicialmente, é de se destacar que a referida lei introduziu em nosso sistema a figura do juiz de garantias, a quem compete o controle da legalidade da investigação criminal e a salvaguarda dos direitos individuais cuja franquia tenha sido reservada à autorização prévia do Poder Judiciário (artigo $3^{\circ}$-B do Código de Processo Penal) ${ }^{51}$.

Tal alteração já era propugnada por parcela significativa da doutrina, que via com maus olhos o fato de o juízo de pré-admissibilidade da acusação ser realizado pelo mesmo que proferiria a sentença ao fim do processo. Nesse sentido, o chamado juiz garante da investigação preliminar seria aquele que atua na instrução preliminar para decidir acerca das providências que lhe são inerentes, não atuando, porém, na fase processual, a fim de que seja resguardada sua imparcialidade ${ }^{52}$.

Também ao juiz de garantias cabe, na forma do inciso XIV do novel artigo $3^{\circ}$-B, examinar os elementos de informação e decidir sobre o recebimento da denúncia ou queixa, nos termos do artigo 399 do Código, momento que cessa sua competência, conforme o caput do artigo $3^{\circ}-\mathrm{C}$.

O parágrafo $3^{\circ}$ do artigo $3^{\circ}$-C, por sua vez, incluiu no ordenamento processual penal brasileiro a inovadora previsão de exclusão física do material pertinente à investigação em relação aos autos principais da ação penal, in verbis:

\footnotetext{
“Os autos que compõem as matérias de competência do juiz das garantias ficarão acautelados na secretaria desse juízo, à disposição do Ministério Público e da defesa, e não serão apensados aos autos do processo enviados ao juiz da instrução e julgamento, ressalvados os documentos relativos às provas irrepetíveis, medidas de obtenção de provas ou de antecipação de provas, que deverão ser remetidos para apensamento em apartado.”
}

\footnotetext{
${ }^{51}$ Ibidem, p. 330. Note-se que, em decisão cautelar proferida em 22/01/2020 no bojo das Ações Diretas de Inconstitucionalidade 6298, 6299, 6300 e 6305, o Ministro Luiz Fux suspendeu por tempo indeterminado a eficácia das regras do Pacote Anticrime (Lei 13.964/2019) que instituem a figura do juiz das garantias.

${ }^{52}$ No mesmo sentido: GRINOVER, Ada Pellegrini. Verdade real e verdade formal? Um falso problema. In: PEREIRA, Flávio Cardoso. Verdade e prova no processo penal: Estudos em homenagem ao professor Michele Taruffo, $1^{\text {a }}$ ed. Brasília: Gazeta Jurídica, 2016, p. 8.
} 
Quanto à regra da exclusão do inquérito dos autos do processo também, como explicam $^{53}$, a inovação legislativa adotou modelo semelhante ao italiano, que contempla a regra de eliminação dos autos da ação penal de todas as peças da investigação preliminar, exceto o laudo do corpo de delito e as provas antecipadas, produzidas em incidente próprio, tudo a fim de garantir a chamada originalidade do processo penal. Para esta corrente, a exclusão dos elementos informativos é medida necessária para evitar-se a contaminação do juiz sentenciante e garantir-se que a valoração probatória repousará somente sobre as provas produzidas sob o crivo do contraditório, ressalvadas as exceções legais - sobretudo no procedimento do júri, em que os juízes leigos não fundamentam a decisão proferida, julgando segundo sua íntima convicção.

Entretanto, salta aos olhos que, em aparente contradição com o artigo $3^{\circ}$-C, $\S 3^{\circ}$, o artigo 12 do Código não sofreu qualquer alteração e continua a determinar que $o$ inquérito policial acompanhará a denúncia ou queixa sempre que lhes servir de base.

Sem qualquer pretensão de encerrar o debate que apenas se inicia com a entrada em vigor da nova lei, entende-se que a compatibilização das previsões passa pela distinção já abordada entre elementos de informação repetíveis e não-repetíveis, e assim em razão da ressalva presente na parte final do supracitado parágrafo $3^{\circ}$ : "ressalvados os documentos relativos às provas irrepetíveis, medidas de obtenção de provas ou de antecipação de provas, que deverão ser remetidos para apensamento em apartado".

Nesse sentido, a interpretação conjunta dos dispositivos legais parece sugerir que, no novo sistema, como regra geral, deverão as peças do inquérito policial acompanhar a denúncia ou queixa tão-somente para que possa o juiz das garantias decidir acerca de seu recebimento ou rejeição (artigo $3^{\circ}$-B, inciso XIV), momento em que se encerra a sua competência (artigo $3^{\circ}$-C, caput). Recebida a denúncia pelo juiz garante, tem início a atuação do juiz da instrução e julgamento, que, no entanto, não terá acesso à documentação dos atos da fase pré-processual, exceção feita às provas irrepetíveis, medidas de obtenção de provas ou de antecipação de provas (artigo $3^{\circ}$-C, parágrafo $3^{\circ}$ ).

Em outros termos, a incidência do disposto artigo 12 passa a estar ligada à jurisdição do juiz de garantias, que deve ter pleno acesso aos elementos informativos do inquérito a

\footnotetext{
${ }^{53}$ GLOECKNER, Ricardo Jacobsen; LOPES JR. Aury. Investigação preliminar no processo penal, $6^{a}$ ed. São Paulo: Saraiva, 2014, p. 327.
} 
fim de poder exercer suas atribuições enumeradas nos incisos $3^{\circ}-\mathrm{B}$, incluindo a de examinar o preenchimento dos pressupostos para o recebimento da peça acusatória. Contudo, uma vez proferida a decisão de recebimento, ficarão as peças do inquérito acauteladas na secretaria do juízo das garantias e à disposição das partes, não instruindo, portanto, os autos que serão submetidos à apreciação do juiz da instrução. É dizer, este somente terá conhecimento dos elementos de provas efetivamente produzidos durante a instrução processual realizada sob o crivo do contraditório, bem como a eventuais provas irrepetíveis ou antecipadas, que serão apensadas em apartado à ação penal (parte final do $\S 3^{\circ}$ do artigo $3^{\circ}-\mathrm{C}$ ).

Buscou-se, assim, evitar de forma mais efetiva o risco de que o juiz responsável por emitir a sentença penal tenha seu convencimento maculado pelas impressões causadas por elementos de informação cuja finalidade é diversa - cautela esta que não se mostra despicienda, como demonstrou o experimento descrito no item 4.1. do presente trabalho. Isso porque, embora tenha sido forjado com semelhante espírito, é certo que o texto do artigo 155 não era suficiente de realizar a finalidade prática pretendida, a saber, a de evitar a indevida transcendência probatória dos atos de investigação e garantir o julgamento efetivamente contraditório.

Neste sentido, a disciplina adotada contribui para dar concretude ao princípio acusatório que, ao menos em tese, rege nosso sistema processual penal, conforme expressamente passa a prever o artigo $3^{\circ}$-A do Código de Processo Penal, também inserido pela Lei n ${ }^{\circ} 13.964 / 19$, e segundo o qual: “O processo penal terá estrutura acusatória, vedadas a iniciativa do juiz na fase de investigação e a substituição da atuação probatória do órgão de acusação".

Em todo o caso, ainda que venha a prevalecer o entendimento aqui esposado, parece ter o legislador perdido a oportunidade de adequar a redação do artigo 12 à nova sistemática, tornando mais claro seu sentido e evitando a insegurança jurídica que poderá emergir da aparente incongruência.

\section{Considerações finais}

Bem antes da reforma processual penal de 2008, já argumentava a doutrina que, no Direito brasileiro, não poderia "nenhum veredicto condenatório embasar-se ou sequer 
apoiar-se em provas que não hajam passado pelo crivo do contraditório e da ampla defesa, enquanto direitos fundamentais da pessoa humana, tão bem proclamados na Constituição democrática de $1988^{\prime \prime 54}$.

Por isso, sempre pairaram dúvidas acerca da transcendência valorativa dos elementos de informação do inquérito para a fase processual, que não puderam ser dissolvidas pela nova redação dada ao artigo 155 do Código de Processo Penal pela Lei n ${ }^{\circ} 11.690 / 08$, o qual não teve o condão de afastar o risco de contaminação - consciente ou inconsciente - do juiz sentenciante por aqueles elementos.

Assim, tomando como premissa a função endoprocedimental dos atos do inquérito e, consequentemente, sua eficácia probatória limitada ao momento pré-processual, discutia-se a necessidade de adoção de uma regra de eliminação do processo dos atos de investigação, sem prejuízo da documentação das provas técnicas e antecipadas produzidas em incidente próprio $^{55}$, tudo com vistas a evitar um indesejável desvirtuamento dos elementos de informação cuja função é interna a fase.

Neste sentido veio a inovação trazida no artigo $3^{\circ}-\mathrm{C}$, parágrafo $3^{\circ}$ do Código de Processo Penal, introduzido pela Lei $\mathrm{n}^{\mathrm{o}}$ 13.961/19. Ao tratar da figura, inédita em nosso modelo processual, do juiz de garantias, passa o dispositivo a prever que as peças que compõem as matérias de sua competência - a saber, as que dizem respeito à fase préprocessual - não serão, como regra, apensadas aos autos que serão remetidos à apreciação do juiz da instrução e julgamento, permanecendo acessíveis somente às partes.

Ademais, em que pese ter o artigo 12 do Código permanecido inalterado, entendemos que, a fim de compatibilizá-lo com a nova disciplina, deve-se se considerá-lo aplicável somente até o momento da decisão acerca do recebimento ou não da peça acusatória, a ser proferida pelo juiz das garantias. Recebida a denúncia ou queixa, deverão os atos documentados de investigação ser excluídos dos autos que formarão o processo (ressalvadas, evidentemente, as exceções legais quanto às provas irrepetíveis e antecipadas), de modo que o juiz da causa forme seu convencimento unicamente com base nas provas produzidas no bojo da instrução processual, sob a plena vigência das garantias que lhe são inerentes.

\footnotetext{
${ }^{54}$ TOVO, Paulo Cláudio. Democratização do Inquérito Policial. In: TOVO, Paulo Cláudio (coord.). Estudos de Direito Penal, v. 2. Porto Alegre: Livraria do Advogado, 1999, p. 206.

${ }^{55}$ GLOECKNER, Ricardo Jacobsen; LOPES JR. Aury. Investigação preliminar no processo penal, $6^{a}$ ed. São Paulo: Saraiva, 2014, p. 332.
} 
Não se ignora que qualquer conclusão com ambição de definitividade será prematura, tendo em vista o intenso debate que, desde já, as alterações trazidas pela Lei n 13.964/19 têm despertado; entretanto, em nosso sentir, trata-se, neste particular, de modificação potencialmente tendente a contribuir para viabilizar um julgamento efetivamente contraditório, tal como se almeja em um modelo processual que, conforme passa a rezar o artigo $3^{\circ}$-A do Código, pretenda-se verdadeiramente acusatório.

\section{REFERÊNCIAS}

BADARÓ, Gustavo Henrique Righi Ivahy; GOMES FILHO, Antonio Magalhães. Prova e sucedâneos de prova no processo penal brasileiro. Revista Brasileira de Ciências Criminais, n. 65, mar-abr/2007, p. 175-201.

FERNANDES, Antonio Scarance. Tipicidade e sucedâneos de prova. In: ALMEIDA, José Raul Gavião; FERNANDES, Antonio Scarance; MORAES, Mauricio Zanoide de (coord.). Provas no processo penal: estudo comparado. São Paulo: Saraiva, 2011, p. $13-45$.

FERRAJOLI, Luigi. Direito e razão: teoria do garantismo penal. $3^{\mathrm{a}}$ ed. São Paulo: Ed. Revista dos Tribunais, 2002.

GLOECKNER, Ricardo Jacobsen; LOPES JR. Aury. Investigação preliminar no processo penal, $6^{\text {a }}$ ed. São Paulo: Saraiva, 2014.

GOMES FILHO, Antônio Magalhães. Direito à Prova no Processo Penal. São Paulo: Revista dos Tribunais, 1997.

GRINOVER, Ada Pellegrini. Verdade real e verdade formal? Um falso problema. In: PEREIRA, Flávio Cardoso. Verdade e prova no processo penal: Estudos em homenagem ao professor Michele Taruffo, $1^{\text {a }}$ ed. Brasília: Gazeta Jurídica, 2016, p. 114.

KHALED JR, Salah H. A busca da verdade no processo penal: para além da ambição inquisitorial, $2^{\mathrm{a}}$ ed. Belo Horizonte: Letramento, 2016.

. O caráter alucinatório da evidência e o sentido da atividade probatória: rompendo com a herança inquisitória e a filosofia da consciência. In: PEREIRA, Flávio Cardoso. 
Verdade e prova no processo penal: Estudos em homenagem ao professor Michele

Taruffo, $1^{\text {a }}$ ed. Brasília: Gazeta Jurídica, 2016, p. 289-317.

LOPES JR. Aury. O problema da "verdade" no processo penal. In: PEREIRA, Flávio

Cardoso. Verdade e prova no processo penal: Estudos em homenagem ao professor Michele Taruffo, $1^{\text {a }}$ ed. Brasília: Gazeta Jurídica, 2016, p. 63-84.

MARQUES, José Frederico. Tratado de direito processual penal, v.1. São Paulo: Saraiva, 1980.

NUCCI, Guilherme de Souza. Provas no processo penal, $4^{\mathrm{a}}$ ed. Rio de Janeiro: Forense, 2015.

OLIVEIRA, Eugênio Pacelli de. Curso de processo penal, 10ª ed. Rio de Janeiro: Lumen Juris, 2008.

PACELLI, Eugênio. Verdade judicial e sistema de prova no processo penal brasileiro. In: PEREIRA, Flávio Cardoso. Verdade e prova no processo penal: Estudos em homenagem ao professor Michele Taruffo, $1^{\text {a }}$ ed. Brasília: Gazeta Jurídica, 2016, p. 85-108.

PELLEGRINI GRINOVER, Ada. Influência do Código-Modelo de Processo Penal para Ibero-América na Legislação Latino-Americana. Convergências e Dissonâncias com os Sistemas Italiano e Brasileiro. O Processo em Evolução. Rio de Janeiro: Forense, 1996.

SCHÜNEMANN, Bernd. O juiz como um terceiro manipulado no processo penal? Uma confraternização empírica dos efeitos perseverança e aliança. In: GRECO, Luís (coord.). Estudos de direito penal, direito processual penal e filosofia do direito. São Paulo: Marcial Pons, 2013, p. 205-221.

TARUFFO, Michele. La verità nel processo. In: PEREIRA, Flávio Cardoso. Verdade e prova no processo penal: Estudos em homenagem ao professor Michele Taruffo, $1^{\mathrm{a}}$ ed. Brasília: Gazeta Jurídica, 2016, p. 243-260.

TOURINHO FILHO. Fernando da Costa. Processo Penal, v. 1. São Paulo: Saraiva, 1999.

TOVO, Paulo Cláudio. Democratização do Inquérito Policial. In: TOVO, Paulo Cláudio (coord.). Estudos de Direito Penal, v. 2. Porto Alegre: Livraria do Advogado, 1999. 